\title{
БЕССАРАБИЯ В 1917 ГОДУ: ЭКОНОМИЧЕСКОЕ ПОЛОЖЕНИЕ ТЫЛА РУМЫНСКОГО ФРОНТА
}

\author{
BESSARABIA IN 1917: THE ECONOMIC SITUATION OF THE REAR \\ OF THE ROMANIAN FRONT
}

\author{
М.В. Оськин \\ M.V. Os`kin \\ Институт законоведения и управления Всероссийской полицейской ассоциации, \\ Россия, 300028, г. Тула, ул. Болдина, 98 \\ Institute of Jurisprudence and Management of the All-Russian police association, \\ 98, Boldina st, Tula, 300028, Russia \\ E-mail:maxozv@yandex.ru
}

\begin{abstract}
Аннотация
Вследствие продовольственного кризиса накануне и после Февральской революции 1917 года регионы России частично обособились друг от друга. В наиболее сложном положении оказались прифронтовые губернии, вынужденные кормить сами себя и снабжать фронт. Ближайшим регионом Румынского фронта являлась хлебородная Бессарабская губерния, в которой производились заготовки и для армии, и для тыла. В результате крайней концентрации политики заготовок экономическое положение Бессарабии лишь обострилось, что усугубилось военными заготовками продуктов питания войсками Румынского фронта. Помимо этого, в 1917 г. закупки продовольствия в Бессарабии проводились и румынскими представителями, вынужденными кормить не только войска, но и беженцев. Приоритет снабжения фронта вызвал продовольственные затруднения в городах региона, а нехватка рабочих рук не позволила выйти на предвоенный уровень сбора хлебов. К моменту октябрьского переворота ресурсы Бессарабии оказались истощенными, однако запасы на военных складах позволили на рубеже 1917-1918 г. сравнительно успешно провести демобилизацию русских войск Румынского фронта.
\end{abstract}

\begin{abstract}
The food crisis before and after the February revolution of 1917 resulted in the partial isolation of Russian regions from each other. In the most difficult situation were the front-line provinces, forced to feed themselves and supply the front. The nearest region of the Romanian front was the grain-bearing province of Bessarabia, where preparations were made for the army and for the rear. As a result of the extreme concentration of procurement policy, the economic situation of Bessarabia only worsened, which was aggravated by the military procurement of food by the troops of the Romanian front. Besides, in 1917 purchases of food in Bessarabia were carried out also by the Romanian representatives compelled to feed not only armies, but also refugees. Priority supply of the front caused food difficulties in the cities of the region and a shortage of workers is not allowed to reach the prewar level of collection of breads. By the time of the October revolution, Bessarabia's resources were depleted, but the stocks in military warehouses allowed at the turn of 1917-1918. relatively successfully demobilize the Russian troops of the Romanian front.
\end{abstract}

Ключевые слова: Бессарабская губерния, урожай хлебов, снабжение фронта, Помглавкорум, самоорганизация, уполномоченный Министерства земледелия, революция 1917 года.

Key words: Bessarabia region, harvest loaves, the supply front, Pallavaram, self-organization, the Commissioner of the Ministry of agriculture, the revolution of 1917.

История Бессарабской губернии в годы Первой мировой войны непосредственно связана с историографией русско-румынских взаимоотношений в 1914-1918 гг. Сотрудничество, а 
затем противостояние между союзниками по Антанте на Восточном фронте непосредственно сказалось на Бессарабии. Приграничный с Румынией российский регион испытал на себе массовое передвижение войск, военные заготовки, беженские потоки, эвакуацию соседней страны, развал Румынского фронта и, наконец, румынскую оккупацию Бессарабию на излете войны.

Анализ социально-экономической ситуации в Бессарабской губернии в 1917 г. позволяет представить объективную картину положения тыла Румынского фронта, взаимоотношений русских и румынских союзников в проблемах снабжения войск и мирного населения, политики хлебных закупок в регионе. Исследование взаимосвязанного единства экономических и социальных процессов в крае в революционный период рассматривает совокупность различных факторов нагрузок военного времени для юго-востока России.

Советская историография, в которой выделяются, прежде всего, работы В.Н. Виноградова [Виноградов, 1969; За балканскими фронтами..., 2002], неизменно подчеркивала тяжелое состояние Бессарабии в годы войны и революции, анализируя тяготы военного времени, выпавшие на долю ближайшего тыла Румынского фронта. Немалое внимание уделялось сельскому хозяйству региона в военный и революционный период [Шемяков, 1963], ресурсы которого постепенно истощались военными усилиями страны, а также взаимоотношениям крестьянства с союзной Румынией, которая в начале 1918 г. перешла к прямой интервенции в Бессарабии [Березняков, 1957; Лунгу, 1979]. В современной молдавской историографии период Первой мировой войны характеризуется с противоположных позиций - как возможность региона к постреволюционному витку развития в составе Румынии, а с другой стороны - как борьба молдавского народа с румынскими интервентами [История Бессарабии, 2001; Репида, 2008; Кушко, 2012; Стати, 2014]. Румынский автор характеризует события 1917 г. в Бессарабии в качестве предварительного этапа якобы добровольного присоединения Бессарабии к Румынии [Якоб, 2005]. Эту точку зрения в целом поддерживают и другие румынские исследователи в совместном русско-румынском сборнике, посвященном Румынскому фронту и русско-румынским взаимоотношениям в 1914-1918 гг. [Romănia și Rusia în timpul Primului Război Mondial, 2018].

Источниковой базой советской историографии служили опубликованные сборники документов, в которых были отражены особенности революционного времени в Бессарабии [Революционное движение в 1917 году..., 1964; Большевики Молдавии..., 1967], политические процессы в данном крае [Борьба трудящихся Молдавии..., 1967; За власть Советскую..., 1970], экономические изменения в жизни бессарабского региона.

В августе 1916 г. королевство Румыния вступило в Первую мировую войну, приняв сторону Антанты, что первоначально не несло в себе какой-либо существенной дополнительной нагрузки для России, чьи войска должны были воевать с румынами плечом к плечу на Восточном фронте. Соединения русской 9-й армии П.А. Лечицкого, сражавшиеся в Южных Карпатах и теперь взаимодействовавшие с румынской Северной армией К. Презана, не поменяли своей дислокации. Отправленный в румынскую Добруджу русский 47-й армейский корпус А.М. Зайончковского подчинялся штабу Юго-Западного фронта, и в силу своей относительной малочисленности (около 50 тыс. чел.) не представлял собой проблемного фактора. Снабжение корпуса всеми видами интендантского довольствия осуществлялось через интендантство Юго-Западного фронта с помощью работавшей в юго-западных губерниях России организации уполномоченного Министерства земледелия гофмейстера С.Н. Гербеля в губерниях Одесского военного округа. Для закупок отдельных или требовавшихся немедленно предметов интендантского снабжения на территории Румынии корпус получил денежные средства, так как по соглашению с румынами русские деньги (пусть и по искусственно заниженному курсу) принимались в Румынии 57.

В связи с неудачами на фронте - поражения в Трансильвании и Добрудже, падение Бухареста после проигрыша генерального сражения, последующее отступление в Молдавию - осенью 1916 г. из русских войск в Румынии формируется уже Дунайская армия, а к

\footnotetext{
${ }^{57}$ Российский государственный военно-исторический архив (далее РГВИА). Ф. 2072. Оп. 1. Д. 400. Л. 60.
} 
концу года - целый фронт из четырех армий. Приток русских войск в Румынию - более 1 млн чел. - в 20 раз увеличил количество бойцов в юго-западном углу Восточного фронта в сравнении с августом. Слабость железнодорожной инфраструктуры, не позволявшая в надлежащей степени снабжать такую массу войск, увеличила издержки ближайших к Румынскому фронту регионов - прежде всего, оставшейся под контролем союзников по Антанте территории румынской Молдавии и русской Бессарабской губернии.

Фронтирным регионом, связывавшим Россию и Румынию, являлась Бессарабская губерния, территория которой подчинялась штабу Одесского военного округа, а в отношении военных реквизиций - командованию Юго-Западного фронта. Нейтралитет Румынии в первые два года войны означал, что губерния оказалась в войсковом тылу. Положительным моментом именно для Бессарабии стало то обстоятельство, что регион большей своей частью примыкал к нейтральной Румынии, и лишь Хотинский уезд оказался близ линии фронта на границе с Буковиной, в 1914-1915 гг. переходившей у русских и австрийцев из рук в руки. Предполагавшиеся в 1915 г. эвакуационные мероприятия вследствие отступления русских армий так и остались предположениями, ибо южный фас Восточного фронта удалось удержать. Распространение военных действий на Румынию с осени 1916 г. сделало Бессарабию приграничной территорией, что повлекло за собой резкое усиление издержек военного времени для этого региона. Армейские закупки и питание проходящих войск, наплыв румынских беженцев, увеличение непосредственной работы губернии на нужды фронта (госпитали, гужевая и подводная повинности крестьянства, борьба с эпидемическими заболеваниями и проч.) поставили Бессарабию последнего года участия России в Первой мировой войне в ряд регионов, непосредственно затронутых войной. Худшим положение было лишь в тех губерниях, на территории которых велись боевые действия и располагался позиционный фронт, а население полностью эвакуировалось в тыл. Соответственно, до того сравнительно благополучное экономическое положение Бессарабской губернии, обусловленное значительными избытками сельскохозяйственного производства, было подвергнуто дополнительным нелегким испытаниям.

Нарастание неблагоприятных тенденций в экономике края проявилось достаточно быстро. В 1916 г. в Российской империи стали резко расти цены на продукты питания, так как до войны сельское хозяйство в отношении получения прибыли на затраченный капитал и труд было поставлено в самое худшее положение в сравнении с другими отраслями народного хозяйства. Во время войны, в условиях резкого подорожания предметов первой необходимости и промышленных товаров вести хозяйство без убытка при условии сохранения прежних цен на хлеб, стало тяжело. Поднялись цены на рабочие руки и инвентарь, что сделало дороже производство продукции сельского хозяйства. В Бессарабской губернии поденная плата выросла с 30-60 коп. в 1913 г. до 0.60-1.50 в 1916 г., то есть вдвое, а «если принять во внимание вздорожание продовольствия, то цены на рабочие руки за время войны возросли в 3 раза, не считая того, что качество и производительность их значительно понизились». Пример некоторых цен на продовольствие (1913 г. / июнь 1916 г.): соль - 0.30 (1.10) за пуд, сало свиное - 8.00 (20.00), крупа гречневая - 1.80 (3.60), пшено - 1.00 (2.40), сахар-песок - 4.80 (6.80), масло сливочное - 24.00 (40.00), пшеничная мука - $2.00(3.20)$, рис - $3.60(6.80){ }^{58}$. Остановить инфляцию могла только система твердых цен на продукты питания.

Доклад чрезвычайного Кишиневского уездного земского собрания от 5 июля 1916 г. по вопросу об установлении твердых цен на хлеб показывал: «Если Бессарабская губерния и в части Кишиневский уезд, несмотря на изобилие производства в них продуктов потребления, нуждаются в целой организации для борьбы с дороговизной этих продуктов, то нечего и говорить о том, что нужда в предметах, которые совершенно не производятся в пределах губернии, чрезмерно велика. Между тем некоторые предметы настолько же необходимы, насколько необходимы и предметы первой необходимости. Отсутствие этих предметов и чрезвычайная их дороговизна крайне неблагоприятно отражается на ведении сельского хозяйства, про-

\footnotetext{
${ }^{58}$ Государственный архив Российской Федерации (далее ГА РФ). Ф. 6831. Оп. 1. Д. 462. Л. 96об.
} 
изводящего продукты продовольствия» ${ }^{59}$. Удовлетворить в полной мере интересы всех сторон (производители и потребители, покупатели и продавцы) было невозможно, а потому следовало во главу угла ставить интересы государства и армии, что предполагало ведение экономической политики в соответствии с твердыми ценами на продовольствие.

Установление твердых цен в сентябре 1916 г. на все хлеба (основные хлеба подверглись государственному регулированию ранее) позволило региону выполнить свои обязательства не только по снабжению армии, но и по выполнению хлебной разверстки. Уже к середине зимы Бессарабия, в которой хлеб закупался путем сделок купли-продажи, а не реквизиции, выполнила свой план на $80 \%$. На 6 февраля 1917 г. в Бессарабской губернии было закуплено около 32 млн пудов различных хлебов и бобовых ${ }^{60}$, которые в первую голову поставлялись действующей армии, а затем - в потребляющие регионы Центральной России. Остальное, и более того, было добрано после Февральской революции. По тем же твердым ценам происходила и реквизиция фуража, «по коим надлежит рассчитываться с местным населением за реквизированные продукты», воинскими частями у населения: сено -0.80 , солома -0.40 руб. за пуд ${ }^{61}$.

Образование Румынского фронта в декабре 1916 г. наложило на Бессарабию новые и тяжелые обязанности. Во-первых, это поставка продовольствия и фуража 4 армиям, численность которых к моменту Февральской революции превысила миллион человек. Являясь транзитным регионом, сквозь который русские войска спешили на помощь гибнувшей под ударами противника Румынии, Бессарабия должна была кормить этих людей по мере их следования. Слабая транспортная инфраструктура приводила к «пробкам» на железных дорогах, что вынуждало войска переходить к реквизициям на местах. Вовторых, питание войск Румынского фронта в условиях развивающегося в России продовольственного кризиса, бывшего кризисом снабжения, должна была обеспечить Бессарабия, ибо румынские запасы к началу весны оказались истощены и почти полностью выработаны. Если учесть румынских беженцев, то дополнительное число «ртов» в югозападном углу империи выросло на 2 млн чел. В-третьих, население региона было обязано нести различные виды натуральной повинности - дорожную, подводную и оборонную (работа на строительстве тыловых укрепленных линий и инфраструктуры). Так, к концу декабря на саперных работах было задействовано 11 тыс. рабочих на 1100 подводах ${ }^{62}$.

27 ноября генерал-квартирмейстер Ставки Верховного командования М.С. Пустовойтенко телеграфировал Главному полевому интенданту К.Н. Егорьеву: «необходимо иметь в виду, что с отходом всей армии и значительной части населения в Молдавию местные средства столь быстро истощаются, что на сколько-нибудь широкое пользование ими наших войск рассчитывать нельзя» ${ }^{63}$. Местные средства - это ресурсы той территории, на которой располагаются войска и их ближайшие тылы. Военные власти имели право принудительной реквизиции этих ресурсов по твердым ценам, но в данном конкретном случае резкого и быстрого увеличения численности русских войск в Румынии (с 50 тыс. до 1,2 млн чел. за 3 месяца) местные средства оказывались исчерпанными.

Это обстоятельство - необходимость образования запасов продовольствия для прибывающих в Румынию русских войск - было быстро осознано. В тот же день русский представитель при румынском командовании М.А. Беляев сообщил в штаб ЮгоЗападного фронта, которому подчинялась Дунайская армия, что «хотя до сего времени все следующие походным порядком эшелоны получают продовольствие и фураж, однако главрум [В.В. Сахаров] опасается, что быстрое истощение запасов Молдавии при чрезвычайно повысившемся населении не дает возможности удовлетворять все поступающие требования» ${ }^{64}$. То есть запасов зерна могло не хватить и на самих жителей Бессарабии.

\footnotetext{
${ }^{59}$ ГА РФ. Ф. 6809. Оп. 1. Д. 37. Л. 98 об.

${ }^{60}$ Там же. Л. 167.

${ }^{61}$ РГВИА. Ф. 2086. Оп. 1. Д. 70. Л. 191.

${ }^{62}$ РГВИА. Ф. 2006. Оп. 1. Д. 15. Л. 271.

${ }^{63}$ РГВИА. Ф. 2009. Оп. 1. Д. 30. Л. 97.

${ }^{64}$ РГВИА. Ф. 2072. Оп. 1. Д. 33. Л. 443.
} 
Конечно, деревня, даже при обширных продажах зерна войскам и уполномоченным, все равно имела небольшие запасы для собственного питания, но города даже в хлебной Бессарабии, обделяемые централизованными поставками уполномоченных Министерства земледелия, вынужденных в первую очередь работать на снабжение фронта, недополучали требовавшихся для горожан продуктов питания. Кризисные явления в питании городского населения производящих регионов стали проявляться с начала 1916 г. в связи с существенным увеличением закупок для армии и, следовательно, подходом к снабжению городов по остаточному принципу. Поэтому городские управления приступили к закупке предметов первой необходимости и продуктов питания, затем продававшихся в городских лавках по фиксированным ценам (немного выше оптовых и в 1,5-2 раза ниже, нежели у частных торговцев).

Испытывая нехватку денег, шедших на поддержание жизнедеятельности города и обеспечение нуждавшихся слоев населения, в первой половине 1916 г. многие города (в лице губернских и уездных земских управ) занимали ссуды для заготовки продовольствия на 9 месяцев. В конце года следовало отдавать, а было нечем, и города просили об отсрочке и новых кредитах, так как денег не было на продовольственные закупки, не то чтобы отдать ссуду. Из городов Бессарабской губернии Бендеры взяли ссуду в 20 тыс. руб., Сороки - 70 тыс., Бельцы - 150 тыс., Оргеев - 50 тыс., Болград - 30 тыс., Измаил 125 тыс., Рени - 30 тыс., Килия - 30 тыс., Аккерман - 50 тыс., Хотин - 20 тыс., Кишинев 100 тыс. рублей. Однако указанной суммой дело не ограничивалось. Например, с начала 1917 г. Хотинское городское управление стало получать от местной земской управы ежемесячно по 18 тыс. пудов пшеничной муки. Так как следовало рассчитываться тут же, то требовались наличные деньги. В январе Хотин заплатил 90 тыс. руб. за муку и около 20 тыс. за сахар ${ }^{65}$. Так как продовольственный кризис продолжался, города просили об отсрочке выплат по выданным весной 1916 г. продовольственным ссудам.

Пример обустройства городского продовольственного хозяйства дает г. Сороки: «городская управа имеет две собственные лавки, из которых отпускается населению мука, соль, мясные продукты, масло, сахар и другие предметы первой необходимости. При управе имеется склад дров, керосина и подошвенных кож для продажи населению по возможно доступным ценам». Для выпечки хлеба управа отпускает муку в частные хлебопекарни, так как своей у города нет. Управа отметила, что «во избежание недоразумений и нареканий со стороны населения, городское управление старается по возможности отпускать предметы первой необходимости (мука, соль, сахар и керосин) по установленным ценам в две существующие в городе общественные кооперативные лавки Самопомощь" и Нольза"». При этом продукты в городских лавках были в 1,5 раза дешевле, чем на рынке. Вывод: «организация городом снабжения населения предметами первой необходимости является весьма целесообразной как ограждающая население от эксплуатации со стороны торговцев и искусственного повышения цен на эти продукты» ${ }^{6}$.

В свою очередь, Кагульская городская управа 2 марта 1917 г. отчитывалась, что «организация по снабжению местного населения печеным хлебом и сахаром является не только целесообразной, но настоятельно необходимой». Управа отметила, что «до открытия продовольственной за счет казны операции местные мукомолы, хлебопекари и бакалейщики часто без всяких оснований взвинчивали цены на муку, хлеб, сахар и проч. предметы первой необходимости» ${ }^{67}$. Торговцы беззастенчиво наживались, пользуясь продовольственным кризисом в России. Для Бессарабской губернии эта спекуляция была обусловлена образованием в конце 1916 г. Румынского фронта и необходимостью страны обеспечить продовольствием сотни тысяч солдат, переброшенных в юго-западный угол империи. Наиболее близко расположенный к создаваемому в короткие сроки фронту регион должен был в наибольшей степени участвовать в снабжении войск.

\footnotetext{
${ }^{65}$ ГА РФ. Ф. 6831. Оп. 1. Д. 210. Л. 1, 7-8, 11, 13-18, 28, 40.

${ }^{66}$ ГА РФ. Ф. 6831. Оп. 1. Д. 462. Л. 78.

${ }^{67}$ ГА РФ. Ф. 6831 Оп. 1. Д. 68. Л. 73 об.
} 
Главной заботой региональных властей, разумеется, стало обеспечение столицы губернии. В прифронтовых районах горожанам приходилось конкурировать с войсками за снабжение. В заседании 15 октября губернское продовольственное совещание Бессарабской губернии определило, что Кишиневу до нового урожая требуется 1,5 млн пудов пшеницы. Совещание считало, что «ввиду близости фронта и частых железнодорожных перерывов в подвозе и громадной отвлеченности подвод разными экстренными и принудительными повинностями необходимо иметь во всякое время в самом городе запас не менее 300 тыс. пудов пшеницы». Это количество обязался дать губернатор М.М. Воронович как уполномоченный Министерства земледелия в Бессарабской губернии, и для начала - 400 тыс. пудов из Рени, из коих 60 тыс. было перевезено в Кишинев к середине ноября. Однако резко возросшие требования армии (в ноябре на Румынский фронт перебрасывалось три армии, и питать их в пути должны были транзитные губернии), вынудили губернатора отказать в вывозе этого хлеба. Как жаловался в своей телеграмме в МВД от 28 ноября заместитель Вороновича А.В. Синадино, такое решение - недопоставить 340 тыс. пудов пшеницы - «ставит город Кишинев в крайне безвыходное положение не только по вопросу об образовании крайне необходимого запаса, но и в вопросе насущного пропитания». В это время в Кишиневе проживало 120 тыс. чел., которые были обеспечены хлебом только на 5 дней. Сделать Воронович ничего не мог (хлеб пошел войскам), и Кишинев просил дать эти 400 тыс. пудов хлеба если не из Рени, то откуда-то еще. Управление сельской продовольственной части МВД поддержало эту просьбу, но 12 декабря Министерство земледелия телеграфировало, что «относительно обеспечения Кишинева пшеницей бессарабскому уполномоченному предложено обратиться к окружному уполномоченному Гербелю, которому телеграфировано о необходимости озаботиться снабжением Кишинева продовольствием в размере текущих потребностей. Образование в Кишиневе крупных продовольственных запасов ввиду близости к фронту представляется нежелательным» ${ }^{68}$. Воронович не имел достаточных запасов хлеба, так как ими распоряжался прежде всего окружной уполномоченный С.Н. Гербель, которому бессарабский губернатор подчинялся как уполномоченный Министерства земледелия.

Иными словами, в конце 1916 г. в центре считали, что существует угроза дальнейшего отступления и потери Бессарабии, почему города региона недополучали продуктов питания. Укрепление фронта по рубежу реки Серет и удержание союзниками румынской Молдавии отставили вопрос об угрозе Бессарабии, но ситуация не улучшилась. Идя навстречу потерпевшим военную катастрофу румынам, помощник августейшего главнокомандующего армиями Румынского фронта (Помглавкорум) В.В. Сахаров разрешил румынским военным агентам «свободную покупку по всей Бессарабии всех зерновых продуктов, скота и сена» ${ }^{69}$. Данная позиция объяснялась межсоюзническими договоренностями. Осенью 1916 г. находившиеся в Румынии русские войска снабжались румынским хлебом, и теперь, после их истощения, румынские подразделения перешли на русский «кошт». В попытке избежать ненужных трений Сахаров по согласованию с Министерством земледелия и разрешил румынам эти закупки. Тем самым в Бессарабии, конечно, расходовалось продовольствие, но выхода не было подвоз хлеба из тыла вплоть до мая 1917 г. не был налажен в достаточной степени.

Вдобавок к задаче снабжения Румынского фронта Гербель не мог выполнить нарядов еще и потому, что Бессарабская губерния должна была участвовать в поставке пшеницы во Францию, о чем существовали предварительные договоренности с Лондоном и Парижем. В начале января главнокомандующий армиями Юго-Западного фронта А.А. Брусилов разрешил вывоз хлеба для союзников «из губерний Волынской, Подольской и Киевской, оговариваясь, что вывоз пшеницы из Херсонской и Бессарабской губерний зависит от главнокомандующего Румынским фронтом». После запроса в штаб Сахарова и учета мнения министра земледелия А.А. Риттиха, в это время находившегося в Одессе, было решено, что Бессарабия также примет участие в поставках ${ }^{70}$.

\footnotetext{
${ }^{68}$ ГА РФ. Ф. 6831. Оп. 1. Д. 209. Л. 1-4,9.

${ }^{69}$ РГВИА. Ф. 2009. Оп. 1. Д. 123. Л. 279-280.

${ }^{70}$ РГВИА. Ф. 499. Оп. 3. Д. 1577. Л. 5.
} 
Транспортная комиссия Особого Совещания по продовольственному делу считала, что возможно поставить 35-40 млн пудов хлеба союзникам в навигацию 1917 г. Из этого количества Гербель принял на себя 20 млн пудов пшеницы Херсонской и Бессарабской губерний. Цена определялась примерно, так как мировые цены на май 1917 г. еще не были известны, а именно: 3.90 руб. за пуд - мягкая пшеница, 4.20 - твердая и 3.00 - рожь. Однако планы союзных поставок стали проваливаться с самого начала, ибо русская Ставка поставила интересы питания фронта в приоритет перед договоренностями с Англией и Францией. Уже подготовленные Гербелем 1,9 млн пудов пшеницы были запрещены к вывозу Начальником штаба Верховного главнокомандующего М.В. Алексеевым. Телеграмма Алексеева от 5 марта приводила обоснование данного запрета: «ныне ввиду чрезвычайных обстоятельств и полного оскудения запасов на фронтах из-за сокращения подвоза я вынужден часть этой готовой пшеницы, еще не отправленной, взять армиям, а остальное количество, до 10 млн пудов, оставить также на местах для обеспечения мельниц фронта. Для отправления в Архангельск полагаю необходимым собрать пшеницу в более восточных губерниях». Давление союзников продолжилось, и 12 марта Ставка подтвердила, что Гербель должен выполнять распоряжение особого назначения о заготовке пшеницы, но имеющийся в данный момент в его распоряжении «избыток пшеницы» следует отдать фронту, причем отправлять даже на Западный и Северный фронт. До августа 1917 г. Гербелю удалось отправить только 634 тыс. пудов хлеба из предполагавшихся 20 млн пудов ${ }^{71}$.

После Февральской революции, для хода и исхода которой продовольственный кризис выступил важным катализатором событий, обстановка в стране в целом и в Бессарабии в частности не особенно изменилась. Невзирая на теоретические значительные хлебные излишки, Организация Гербеля столкнулась с противоречием между теорией и практикой. На рубеже 1916-1917 г., когда русские и румынские войска, равно и беженцы, перемещались по территории Бессарабии, существенная часть запасов оказалась израсходованной $^{72}$. Вдобавок, часть хлебных ресурсов ушла на Юго-Западный фронт и в некоторые регионы Центральной России и Белоруссии.

Штаб Румынского фронта, в отличие от соседних фронтов, где располагались исключительно русские войска, не имел права забывать о союзниках. Назначенный Временным правительством Верховный главнокомандующий М.В. Алексеев 12 марта телеграфировал В.В. Сахарову, что ему следует немедленно предпринять совместные с румынами действия по выходу из тяжелой ситуации. Алексеев считал, что «растущий недостаток продовольственных припасов в Румынии требует скорейшего осушествления всех возможных мероприятий для борьбы с создавшимся в связи с этим положением. Ввиду сего прошу безотлагательно выработать совместно с румынскими Главной квартирой и правительством и при участии нашей миссии детальный план конкретных мероприятий в этом направлении». Следовало выяснить необходимое румынам количество продовольствия, фуража и интендантского имущества (форма, обувь), «выяснить, какое количество грузов фактически может по условиям транспорта быть подвезено в Румынию сверх необходимого для нужд нашей армии», определить пути эвакуации, и особенно - «на случай движения беженцев под влиянием недостатка продовольствия в Румынии» ${ }^{73}$.

Если сельская местность Юга России имела запасы предыдущих урожаев и, так или иначе, могла самостоятельно регулировать собственные запасы (крестьяне и помещики сами решали продавать или не продавать войскам или румынам хлеб), то города оказались в более сложном положении. Во-первых, вследствие сравнительно слабой организации городского снабжения продуктами питания (в ситуации продовольственного кризиса рынок имел тенденцию скатывания в «черный»). Во-вторых, ввиду меныших финансовых возможностей в сравнении с военными властями.

Весь революционный год городские и земские власти прифронтовых регионов просили у правительства новые субсидии на продукты питания и предметы первой необходи-

\footnotetext{
${ }^{71}$ ГА РФ. Ф. 6831. Оп. 1. Д. 57. Л. 12, 17, 20 об., 56-58, 62 об., 104.

${ }_{72}^{72}$ РГВИА. Ф. 2005. Оп. 1. Д. 81. Л. 268 об.

${ }^{73}$ РГВИА. Ф. 2004. Оп. З. Д. 464. Л. 373.
} 
мости. Так, 20 мая Бендерский городской голова Лопатин просил выдать безвозвратное пособие в 150 тыс. рублей. МВД поддержало просьбу, ибо «нахождение города Бендер в ближайшем тылу, переполнение его войсками и беженцами, наличие в нем усиливающихся эпидемических заболеваний и недостаточность средств у городского управления могут угрожать большими бедствиями не только самому населению города, но и действующей армии». Однако 13 июня бывший министр земледелия А.И. Шингарев, занявший к тому времени пост министра финансов, отказал бендерцам ${ }^{74}$.

В середине июня бессарабское губернское земство ходатайствовало перед МВД о разрешении ему займа до 3 млн руб. - «на усиление оборотных средств земской кассы мелкого кредита, приспособленной для снабжения населения предметами первой необходимости». Но и эта сумма не была получена. Ситуацию частично спасала самоорганизация горожан. Например, весной 1917 г. в Одессе, где с войсками и ранеными насчитывалось более 800 тыс. чел., был введен добровольный налог на зажиточных земляков. Как сообщали одесситы, «самообложение граждан Одессы установлено на добровольных началах, применительно к ставкам подоходного налога, без принудительности». Причина - «критическое финансовое положение Одессы и отсутствие источников» ${ }^{75}$.

К сожалению, сознательность граждан проявлялась не везде. Либо в небольших населенных пунктах просто насчитывалось мало зажиточного элемента. Телеграмма министру земледелия из Ольвиополя 25 апреля сообщила, что «население города Ольвиополя голодает. Некоторые лица, имеющие запасы муки, упорно отказываются в выдаче. Как с такими лицами поступать, гуманные меры не оказывают действия?». Вдобавок, нередким случаем стало мародерство со стороны воинских подразделений. В июне землевладельцы Кагульского уезда жаловались в Министерство продовольствия на «самоуправные действия расквартированных в их районе воинских частей, которые захватывают продовольственные продукты и скот и расхищают сельскохозяйственные машины» ${ }^{76}$. Без хлеба периодически оставалась и столица Бессарабии. В середине лета 1917 г. ставший губернским комиссаром председатель губернской земской управы К.А. Мими телеграфировал, что в Кишиневе и Бендерах мука на исходе и «отсутствие зерна поставит население и местные и проходящие воинские части в критическое положение» ${ }^{77}$.

Сильно ударившим по снабжению армии обстоятельством стал слабый урожай хлеба в Европейской части России, а замечательный урожай Сибири невозможно было вывезти к фронту. По донесениям податных инспекторов на 1 января 1917 г. посевная площадь озимых хлебов в 50 губерниях Европейской России составила 28153 тыс. десятин, меньше площади прошлого года на 335,6 тыс. десятин или на 1,2\%. В том числе у крестьян - 23225,5 тыс. десятин $(82,5 \%)$ и 4 927,5 тыс. десятин $(17,5 \%)$ у частных владельцев. В 1916 г. у крестьян было больше на 88,1 тыс. десятин $(0,4 \%)$, а у владельцев на 247,5 тыс. десятин (4,81 \%). Наибольшее сокращение произошло в Подольской губернии - 122,5 тыс. десятин (на 13,4 \%), Ставропольской - 126,8 тыс. (16,7 \%), Кубанской Области - 106,4 тыс. (10,1 \%) и, главное для Румынского фронта, - в Бессарабской губернии - на 56,5 тыс. десятин (10,1\%). Главная причина сокращения посевов - «недостаток и дороговизна рабочих рук» ${ }^{78}$. Поэтому урожай 1917 г. в Бессарабии составил всего 115,2 млн пудов ${ }^{79}$ - против 141,2 млн пудов в 1916 г.

Помимо слабой урожайности как объективного обстоятельства, в дело снабжения армии вмешивался и субъективный фактор. Российское крестьянство сосредоточивалось на собственном хозяйстве и личном потреблении, не желая продавать продукты питания и пользуясь как слабостью власти, так и опасаясь вероятного голода, видя общую обстанов-

\footnotetext{
${ }^{74}$ ГА РФ. Ф. 6996. Оп. 1. Д. 98. Л. 1, 4.

${ }^{75}$ ГА РФ. Ф. 6831. Оп. 1. Д. 462. Л. 54, 92.

${ }^{76}$ ГА РФ. Ф. 6831. Оп. 1. Д. 14. Л. 59, 287.

${ }^{77}$ РГВИА. Ф. 2086. Оп. 1. Д. 15. Л. 425.

${ }^{78}$ ГА РФ. Ф. 6996. ОП. 1. Д. 277. Л. 54-55об.

${ }^{79}$ Революционное движение в 1917 году и установление советской власти в Молдавии. Кишинев, 1964. С. 60.
} 
ку в государстве. Так, Главный начальник снабжений Румынского фронта А.С. Санников в телеграмме главнокомандующему армиями Юго-Западного фронта Л.Г. Корнилову от 21 июля жаловался, что «вопреки Вашего приказа от 8 июля, местные крестьяне продолжают оказывать противодействие уборке урожая, устанавливая непомерные цены и не позволяя желающим работать. Штабом Киевского округа оставлены на месяц сербы [военнослужащие выведенного в тыл Сербского добровольческого корпуса из бывших австрийских военнопленных], ибо признано, что они работают на оборону. Местные крестьяне запрещают работать сербам и грозят устроить с ними войну» ${ }^{80}$.

В столь нелегкой обстановке продовольственные и фуражные запасы армий Румынского фронта неукоснительно падали, даже в летний, казалось бы, урожайный и климатически выгодный период сокращаясь до недельного уровня в лучшем случае. Обеспечение Румынского фронта к 25 июля 1917 г. в днях ${ }^{81}$ :

Обеспечение Румынского фронта к 25 июля 1917 г. в днях

\begin{tabular}{|l|c|c|c|c|c|}
\hline \multicolumn{1}{|c|}{ Продукт } & 6-я армия & 4-я армия & 9-я армия & 1-я румынская армия & 2-я румынская армия \\
\hline Мука & 9,5 & $113 / 4$ & 16,5 & 1,5 & 8 \\
Крупа & 17,5 & 5 & 5,5 & - & - \\
Соль & 36 & 36 & 15 & 15 & 20,5 \\
Сахар & 25,5 & 53 & 17 & 39 & 16 \\
Жиры & 11 & $93 / 4$ & 6,5 & 11,5 & 7,5 \\
Табак & $43 / 4$ & - & $1 / 4$ & 2 & $1 / 2$ \\
Сушеные овощи & 4 & 2 & 2 & - & 3 \\
Зернофураж & 3 & 4 & 5,5 & $1 / 6$ & - \\
Сено & 3 & $1 / 2$ & $1 / 2$ & - & - \\
Мясо & $1 / 4$ & - & - & - & - \\
Рыба & $13 / 4$ & - & - & $1 / 2$ & 5,5 \\
Консервы & $61 / 3$ & 9,5 & 8 & $11 / 8$ & - \\
Скот & $23 / 4$ & 6 & 4 & - & \\
\hline
\end{tabular}

Запасы фронта в разгар лета по основным продуктам питания (мука, крупа, жиры, мясо и скот), как показывает таблица, составляют около недели. И даже консервов, столь необходимых в наступлении, хватает все на ту же неделю. Рыба не может заменить мясо, ибо ее запасы столь же минимальны (либо вовсе отсутствуют), как и у мяса. Следовательно, опора войск Румынского фронта на близлежащие районы - румынскую Молдавию и русские Бессарабию и Херсонщину в отношении использования местных средств являлась неизбежной, тем более что русская революция изолировала Румынское королевство, оставив его в одиночку на всем Восточном фронте [Hamilton, p. 214].

Повышение твердых цен на хлеб (для Бессарабской губернии, согласно постановлению министра продовольствия от 5 октября, хлебные цены составили 448 коп. за пуд ржи, пшеница -680 , овес -490 , ячмень -410 , просо - 540 , гречиха $-720^{82}$ ), отказ производителей от поставки продовольствия государству, нарастающий в стране общеполитический кризис и, главное для фронта, - раскол личного состава действующей армии по итогам корниловского выступления - все эти факторы отнюдь не способствовали улучшению процесса снабжения войск, на что рассчитывали во Временном правительстве. Ранее предполагалось, что сбор урожая 1917 г. и проявившаяся поддержка режима со стороны кооперативов позволит России продолжить свое участие в войне. С началом осени выяснилось, что такие расчеты являлись фикцией, и прокормить 7-миллионную армию страна, вероятнее всего, уже не сможет. В результате увеличить запасы войск до более чем недельной нормы по-

\footnotetext{
${ }^{80}$ РГВИА. Ф. 2086. Оп. 1. Д. 7. Л. 35.

${ }^{81}$ РГВИА. Ф. 2086. Оп. 1. Д. 15. Л. 545.

${ }^{82}$ ГА РФ. Ф. 1783. Оп. 1. Д. 25. Л. 143-149.
} 
прежнему не удавалось ${ }^{83}$. Вдобавок, чтобы не подвергать войсковые склады угрозе возможного захвата со стороны неприятеля, что при наступившем разложении русских войск представлялось реальным, осенью 1917 г. все хлеба Юга концентрировались в Херсоне, Николаеве и по течению реки Днепр ${ }^{84}$. Отсюда их еще следовало подвезти на фронт.

Вследствие неукоснительного падения возможностей железнодорожного транспорта с середины сентября интендантские службы ходатайствовали перед министром продовольствия С.Н. Прокоповичем о запрете вывоза всех продуктов, керосина, мешков и мануфактуры из прифронтовых губерний, так как войскам оставалось рассчитывать лишь на них. Примечательно, что об этом просил как Главный начальник снабжений армий Румынского фронта А.С. Санников, имевший в своем тылу хлебородные регионы, так и его коллега с Западного фронта В.Н. Минут, могший полагаться на Белоруссию и западные губернии Центральной России ${ }^{85}$. Смысл заключался в том, что для армии стала важной любая опора на местные средства - неважно, сравнительно обильные, как на Румынском фронте, либо скудные, как на Западном.

После октябрьского переворота в условиях нараставшей экономической разрухи Помглавкорум должен был обеспечить демобилизацию вверенных ему войск, каковая задача осложнялась тем обстоятельством, что три армии фронта из четырех располагались в Румынии. В связи с тем, что румыны взяли курс на сохранение собственных ресурсов, штаб фронта должен был обеспечить питание выводимых из королевства русских соединений вплоть до их убытия по домам. Для того же, чтобы прокормить миллион человек в течение не менее чем трех месяцев, требовалась стабильная обстановка в ближайшем тылу, так как основные продовольственные склады (магазины) находились в Бессарабии, а запасы населения вполне могли стать последним ресурсом на случай реквизиций.

Самовольно уходившие в войсковой тыл отдельные подразделения и массы дезертиров грабили территорию Бессарабии, и борьба с этими явлениями также возлагалась на штаб фронта. Например, в начале декабря Хотинская уездная продовольственная управа телеграфировала в Одессу, что работа невозможна ввиду «повального грабежа взятых на учет и реквизированных продуктов», в прифронтовой полосе полностью отсутствует мука, а в городе и местечках идут погромы. Войска громили продовольственные склады продуправы, не позволяя наладить снабжение горожан ${ }^{86}$.

Вряд ли новый Помглавкорум Д.Г. Щербачев, занявший свой пост в апреле, не имевший надежных войск, мог остановить стихию. Его надежда возлагалась на командование всех уровней, поддержку румынской стороны и сознательность ряда русских соединений. В штабе фронта прекрасно понимали, что при самочинном разгроме складов, инфраструктуры и грабеже местного населения все еще остающимся в окопах людям придется несладко. Соответственно, телеграмма Щербачева от 15 декабря указывала, что «демобилизация должна производиться по подробно разработанному плану. Если войска начнут самовольный общий отход, то люди и лошади погибнут по дороге от голода и холода». Помглавкорум напоминал: «мы не должны забывать, что находимся на территории союзного нам государства, которое принимает меры для сохранения своей территории от грабежей» ${ }^{87}$. К сожалению, следствием всех этих событий стала оккупация российской Бессарабии румынским союзником России по Первой мировой войне.

Военная разруха не коснулась Бессарабии непосредственно, так как враг не дошел до нее, застряв в Буковине и Северной Румынии, однако статус ближнего тыла Юго-Западного, а затем Румынского фронтов поставил регион в столь нелегкое положение, что выходить из него пришлось экстраординарными мерами. Притом Бессарабия как ближайший тыловой регион страдала от всех издержек войны: людских потоков, продовольственных заготовок, угрозы эпидемий,

\footnotetext{
${ }^{83}$ РГВИА. Ф. 2086. Оп. 1. Д. 17. Л. 13.

${ }^{84}$ ГА РФ. Ф. 6831. Оп. 1. Д. 463. Л. 37.

${ }^{85}$ ГА РФ. Ф. 1783. Оп. 1. Д. 174. Л. 226-227, 286.

${ }^{86}$ Российский государственный архив экономики. Ф. 1943. Оп. 3. Д. 13. Л. 1.

${ }^{87}$ ГА РФ. Ф. 5936. ОП. 1. Д. 9. Л. 2.
} 
наплыва беженцев и прочего негатива военного времени. Например, телеграмма гофмейстеру Д.И. Засядко от 13 февраля 1917 г. от особоуполномоченного российского отделения Красного Креста Тарасова о санитарном состоянии прифронтовой полосы в Румынии констатировала, что «несмотря на отсутствие боев, ежедневная убыль достигает значительных размеров вследствие серьезного развития эпидемии возвратного тифа. Главный источник заразы - голодающее население, в особенности беженцы из Валахии, осевшие в прифронтовой полосе, положение которых поистине ужасное». Тарасов предупреждал об угрозе холерной эпидемии и просил принять срочные меры, в том числе усилить питание и вакцинацию, а также сформировать эпидемиологический отряд для создания организации по ликвидации бедствия ${ }^{88}$.

Тяжелой по своим климатическим условиям зимой 1916-1917 г. ставшая в результате поражений в Румынии ближайшим тылом Румынского фронта Бессарабская губерния Российской империи сыграла важнейшую роль в деле снабжения продовольствием и фуражом русскорумынских войск и румынских беженцев. Нехватка транспортных мощностей и слабость инфраструктуры в пограничной полосе между Россией и Румынией не позволяли в должной мере обеспечить питанием солдат, однако удалось и не допустить голодовок. Хлебные запасы производящей Бессарабской губернии стали тем ресурсом, что зимой 1917 г. существенно выправил крайне неблагоприятно складывавшуюся в смысле продовольственного обеспечения обстановку на Румынском театре военных действий. Колебания подвоза непосредственно влияли на обеспечение личного состава войск, находившихся в окопах Румынского фронта.

Продовольственные органы Бессарабии во главе с уполномоченными Особого Совещания по продовольственному делу и Министерства земледелия различного уровня и полномочий - С.Н. Гербелем, М.М. Вороновичем, К.А. Мими - выполнили поставленную перед ними нелегкую задачу продовольствования нового фронта. В период разворачивавшегося в России революционного процесса 1917 года экономическая обстановка в Бессарабии ухудшилась, что было следствием как невысокого урожая, так и падением подвоза продовольствия и фуража фронту, что вынуждало военные власти усиливать реквизиционную практику в ближайшем войсковом тылу. Первыми пострадавшими акторами региона стали города, чья конкуренция за истощавшиеся ресурсы с армией являлась заведомо проигрышной, а к концу года демобилизация русской армии и выход России из войны ввергли приграничные регионы страны в экономический хаос, усугублявшийся ростками начинавшейся гражданской войны. Для Бессарабии военная эпопея завершилась румынской оккупацией и контролем румынских властей над экономикой региона в ситуации ведения переговоров о перемирии с Германией и ее союзниками.

\section{Список литературы}

1. Березняков Н.В. 1957. Борьба трудящихся Бессарабии против интервентов в 1917-1920 гг. Кишинев, Госиздат Молдавии, 316.

2. Большевики Молдавии и Румынского фронта в борьбе за власть Советов (март 1917 - январь 1918 г.). 1967. Кишинев, Картя молдовеняскэ, 449.

3. Борьба трудящихся Молдавии против интервентов и внутренней контрреволюции (1917-1920 гг.). 1967. Кишинев, Картя молдовеняскэ, 684.

4. Виноградов В.Н. 1969. Румыния в годы Первой мировой войны. М., Наука, 370.

5. За балканскими фронтами Первой мировой войны. 2002. М., Индрик, 502.

6. За власть Советскую. Борьба трудящихся Молдавии против интервентов и внутренней контрреволюции (1917-1920 гг.). 1970. Кишинев, 403.

7. История Бессарабии (От истоков до 1998 года). 2001. Кишинев, 352.

8. Кушко А., Таки В. 2012. Бессарабия в составе Российской империи (1812-1917). М., Новое лит. обозрение, 392.

9. Лунгу В. 1979. Политика террора и грабежа в Бессарабии 1918-1920. Кишинев, Картя молдовеняскэ, 216.

10. Революционное движение в 1917 году и установление советской власти в Молдавии. 1964. Кишинев, Картя молдовеняскэ, 632.

\footnotetext{
${ }^{88}$ ГА РФ. Ф. 1001. Оп. 1. Д. 224. Л. 2.
} 
11. Репида Л.Е. 2008. Суверенная Молдова. История и современность. Кишинев, ИПФ Центральная типография. 384.

12. Стати В. 2014. История Молдовы. Кишинев, 489.

13. Шемяков Д.Е. 1963. К вопросу о товарности зернового хозяйства Бессарабии в эпоху империализма (конец XIX в. - 1917 г.). Ежегодник по аграрной истории Восточной Европы 1961 г. Рига, 458.

14. Якоб Г. 2005. Румыны в период становления национальных государств (1859-1918). История Румынии. М., Весь мир, 678.

15. Hamilton R. Decisions for War, 1914-1917. Cambridge, 2005.

16. Romănia și Rusia în timpul Primului Război Mondial. București, 2018.

\section{References}

1. Bereznyakov N.V. 1957. Bor'ba trudyashchihsya Bessarabii protiv interventov v 1917-1920 gg. [The struggle of the workers of Bessarabia against the invaders in 1917-1920]. Kishinev: Gosizdat Moldavii, 316.

2. Bol'sheviki Moldavii i Rumynskogo fronta v bor'be za vlast' Sovetov (mart 1917 - yanvar' 1918 g.) [Bolsheviks of Moldova and the Romanian front in the struggle for power of the Soviets (March 1917 - January 1918)]. 1967. Kishinev, Kartya moldovenyaske, 449.

3. Bor'ba trudyashchihsya Moldavii protiv interventov i vnutrennej kontrrevolyucii (19171920 gg.) [The struggle of the workers of Moldova against the interventionists and the internal counterrevolution (1917-1920)]. 1967. Kishinev, Kartya moldovenyaske, 684.

4. Vinogradov V.N. 1969. Rumyniya v gody Pervoj mirovoj vojny [Romania during World War I]. M., Nauka, 370.

5. Za balkanskimi frontami Pervoj mirovoj vojny [Behind the Balkan fronts of the First World War]. 2002. M., Indrik, 502.

6. Za vlast' Sovetskuyu. Bor'ba trudyashchihsya Moldavii protiv interventov i vnutrennej kontrrevolyucii (1917-1920 gg.) [For Soviet power. The struggle of the workers of Moldova against the interventionists and the internal counter-revolution (1917-1920)]. 1970. Kishinev, 403.

7. Istoriya Bessarabii (Ot istokov do 1998 goda) [History of Bessarabia (from its origins to 1998)]. 2001. Kishinev, 352.

8. Kushko A., Taki V. Bessarabiya v sostave Rossijskoj imperii (1812-1917) [Bessarabia in the Russian Empire (1812-1917)]. 2012. M., Novoe lit. obozrenie, 392.

9. Lungu V. 1979. Politika terrora i grabezha v Bessarabii 1918-1920 [The policy of terror and plunder in Bessarabia 1918-1920]. Kishinev, Kartya moldovenyaske, 216.

10. Revolyucionnoe dvizhenie v 1917 godu i ustanovlenie sovetskoj vlasti v Moldavii [The revolutionary movement in 1917 and the establishment of Soviet power in Moldova]. 1964. Kishinev, Kartya moldovenyaske, 632.

11. Repida L.E. 2008. Suverennaya Moldova. Istoriya i sovremennost' [Moldova. History and modernity]. Kishinev, IPF Central'naya tipografiya, 384.

12. Stati V. 2014. Istoriya Moldovy [History of Moldova]. Kishinev, 489.

13. Shemyakov D.E. 1963. K voprosu o tovarnosti zernovogo hozyajstva Bessarabii v epohu imperializma (konec XIX v. - 1917g.) [To the question of marketability of grain economy of Bessarabia in an era of imperialism (the end of XIX century - 1917]. Ezhegodnik po agrarnoj istorii Vostochnoj Evropy $1961 \mathrm{~g}$. Riga, 458.

14. Yakob G. 2005. Rumyny v period stanovleniya nacional'nyh gosudarstv (1859-1918) [Romanians during the formation of nation States (1859-1918)]. Istoriya Rumynii. M., Ves' mir, 678.

15. Hamilton R. Decisions for War, 1914-1917. Cambridge, 2005 (in England).

16. Romănia și Rusia în timpul Primului Război Mondial [Romania and Russia during the First World War]. București, 2018 (in Romanian and in Russian).

\section{Ссылка для цитирования статьи Link for article citation}

Оськин М.В. 2020. Бессарабия в 1917 году: экономическое положение тыла румынского фронта. Via in tempore. История. Политология, 47(1): 139-150. DOI 10.18413/2687-0967-2020-47-1-139-150

Os'kin M.V. 2020. Bessarabia in 1917: the economic situation of the rear of the Romanian front. Via in tempore. History and political science, 47(1): 139-150 (in Russian).

DOI 10.18413/2687-0967-2020-47-1-139-150 